\title{
Changes in Ground-Water Levels in Selected Wells in the Arkansas River Alluvial Aquifer Downstream from Pueblo Reservoir, Southeastern Colorado, 1965-2001
}

The Arkansas River alluvial aquifer of Quaternary age underlies the Arkansas River in southeastern Colorado (fig. 1). The aquifer is 1 to 6 miles wide and extends about 150 miles from Pueblo County through Otero, Crowley, Bent, and Prowers Counties to the Colorado-Kansas State line (figs. 6-9). The aquifer is hydraulically connected to the Arkansas River and is underlain by relatively impermeable bedrock of Cretaceous age. The aquifer is as much as 200 feet thick and consists of unconsolidated clay, silt, sand, and gravel. Depth to water generally is less than 60 feet below land surface (Voegeli and
Hershey, 1965; Weist, 1965; Lohman and others, 1974).

The U.S. Geological Survey (USGS) has measured water levels in wells completed in the Arkansas River alluvial aquifer since about 1965 for various programs. Currently (2002) the USGS measures water levels during the spring and fall of each year in 35 wells in the aquifer, in cooperation with the Southeastern Colorado Water Conservancy District (SECWCD) (figs. 6-9). Long-term, systematic water-level measurements are needed to monitor stresses on the aquifer that affect recharge and ground-

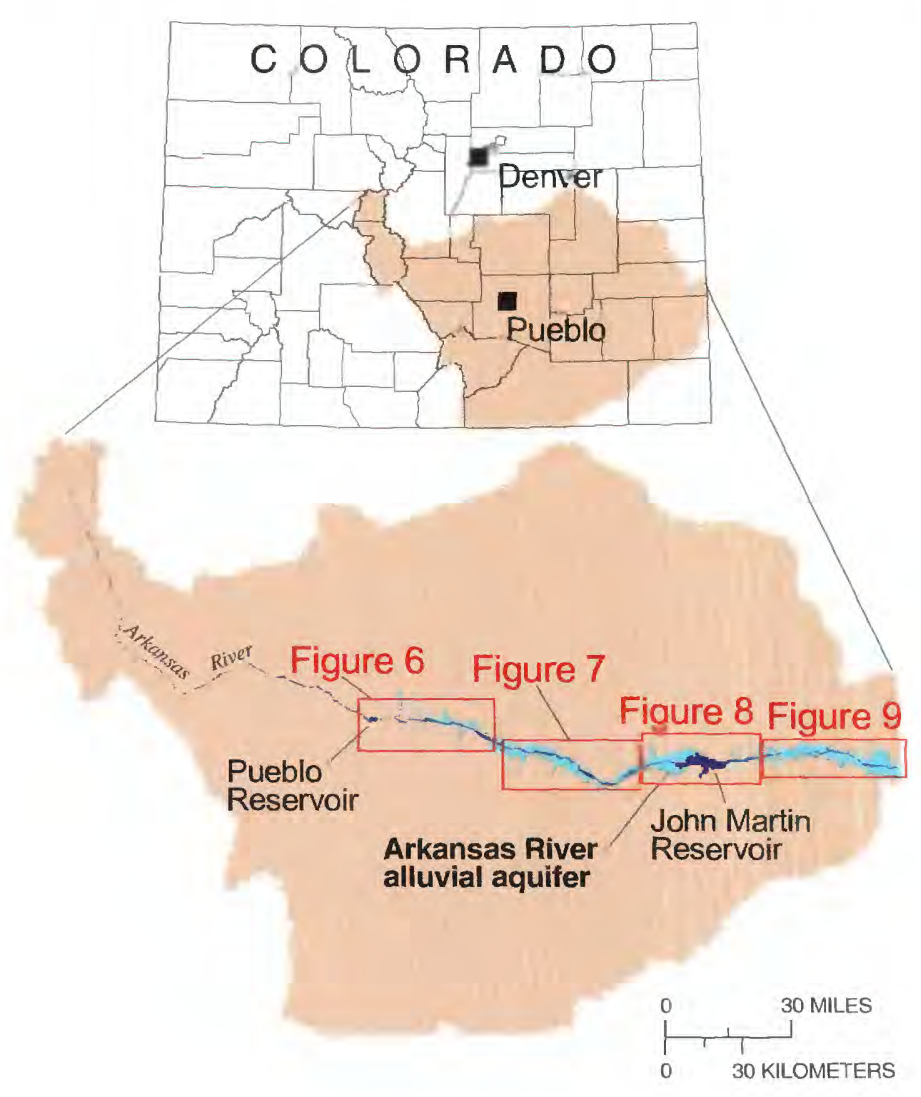

Figure 1. Arkansas River Basin and alluvial aquifer between Pueblo Reservoir and Colorado-Kansas State line.

water storage (Taylor and Alley, 2001). The purpose of this report is to present ground-water levels based on measurements made during the spring seasons in 1965-2001 in selected wells completed in the Arkansas River alluvial aquifer and to relate changes to streamflow and wateruse impacts. The data are stored in the USGS National Water Information System (NWIS) data base and are available on the USGS national Web site,

http://water.usgs.gov/nwis.

\section{FACTORS AFFECTING WATER LEVELS}

Ground-water levels in the Arkansas River alluvial aquifer are affected by many factors, including (1) infiltration from the Arkansas River and its tributaries and from floodwaters; (2) infiltration from irrigation canals; (3) infiltration of irrigation water, rainfall, and snowmelt; (4) ground-water pumping from the aquifer; and (5) changes in elevation of the riverbed (Bossong, 2000). The primary source of recharge is the Arkansas River and its tributaries. Streamflow in the Arkansas River at Pueblo and downstream is largely controlled by Pueblo Reservoir, located upstream from the city of Pueblo, and by John Martin Reservoir (fig. 1). Recharge also occurs from infiltration of irrigation water that is diverted from the river and(or) its tributaries. During periods of high streamflow in the river, more river water is used for irrigation and less ground water is pumped from the aquifer, which can result in higher water levels in the aquifer than during periods of lower streamflow. Water levels in the aquifer in close proximity to the river channel can be influenced by changes in streamflow over a short period of time, whereas water levels in the aquifer distant from the river might be influenced by changes in streamflow over the long term by an overall increase in availability of surface water for irrigation. 


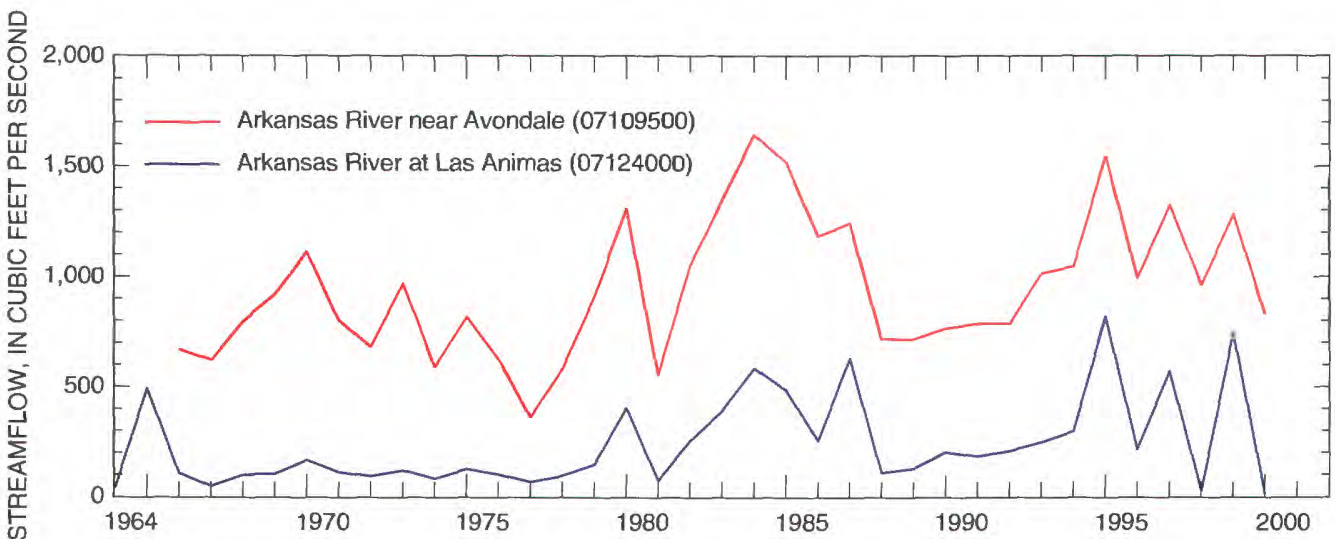

Figure 2. Mean annual streamflow upstream from John Martin Reservoir, 1964-2000.

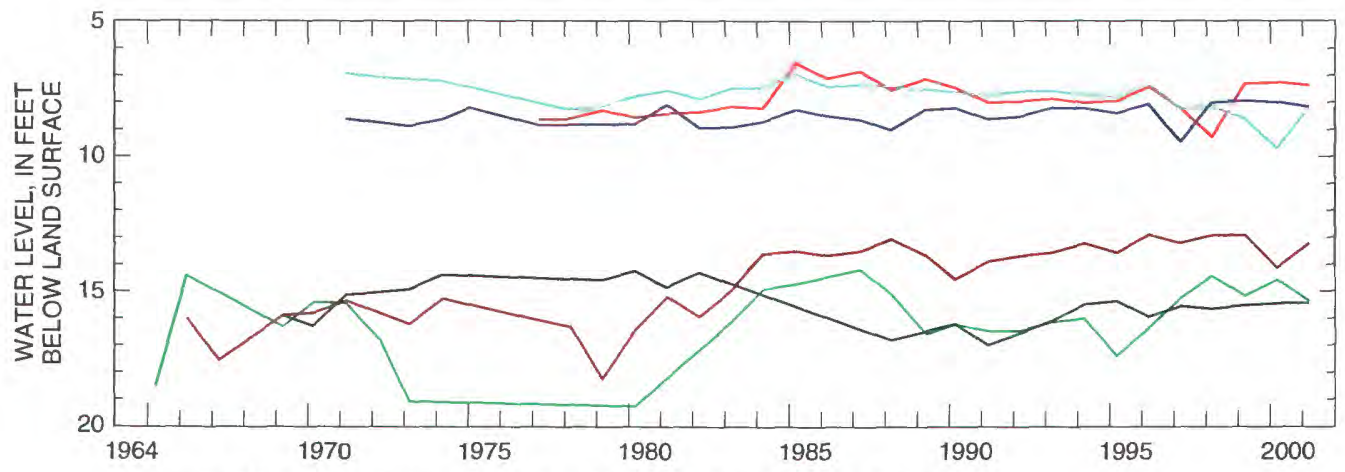

\section{EXPLANATION}

(1)SC20-64-36DDD2

(2) $\mathrm{SC} 21-62-9 \mathrm{CCC}$

(3) SC21-62-2CBC

(4) SC21-61-18ABC

(5) SC21-61-15ADD

(6) SC21-60-29CDD2

Figure 3. Water levels in selected wells in Pueblo County, 1965-2001.

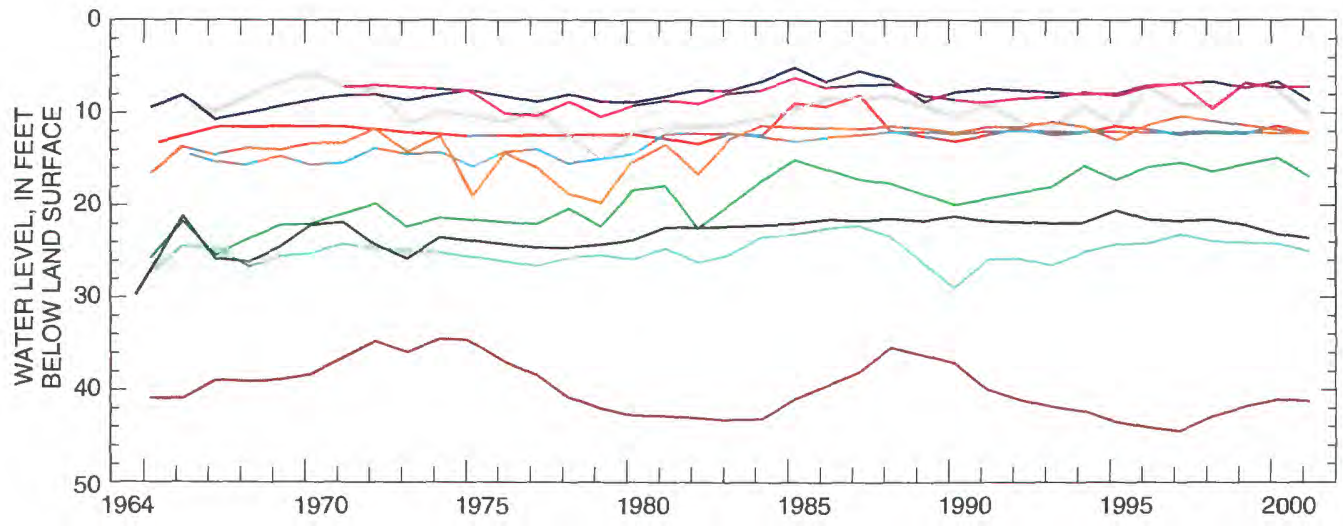

EXPLANATION

(1) SC22-59-18CCC

(2)SC22-59-35BDD

(3) $\mathrm{SC} 22-58-8 \mathrm{BBB}$

(4) $\mathrm{SC22}-58-27 \mathrm{BCC}$

(5) SC22-57-18AAA

(6)SC23-57-5BAD3

(7) SC23-56-20AAA

(8)SC23-56-23AAB

(9)SC23-55-31BAA

(10)SC23-54-13AAA3

Figure 4. Water levels in selected wells in Crowley and Otero Counties, 1965-2001.

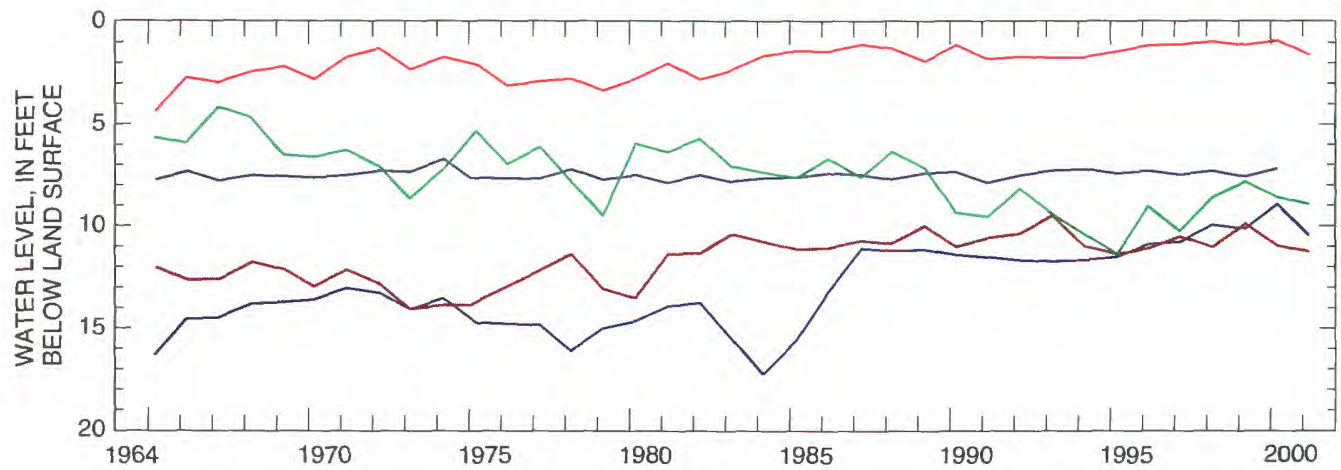

EXPLANATION

(1)SC23-53-4BBB2

(2) $\mathrm{SC} 23-53-1 \mathrm{BAB}$

(3)SC23-52-4AAA

(4) SC23-52-26BAA

(5)SC23-51-8DCC

Figure 5. Water levels in selected wells in Bent County upstream from John Martin Reservoir, 1965-2001. 


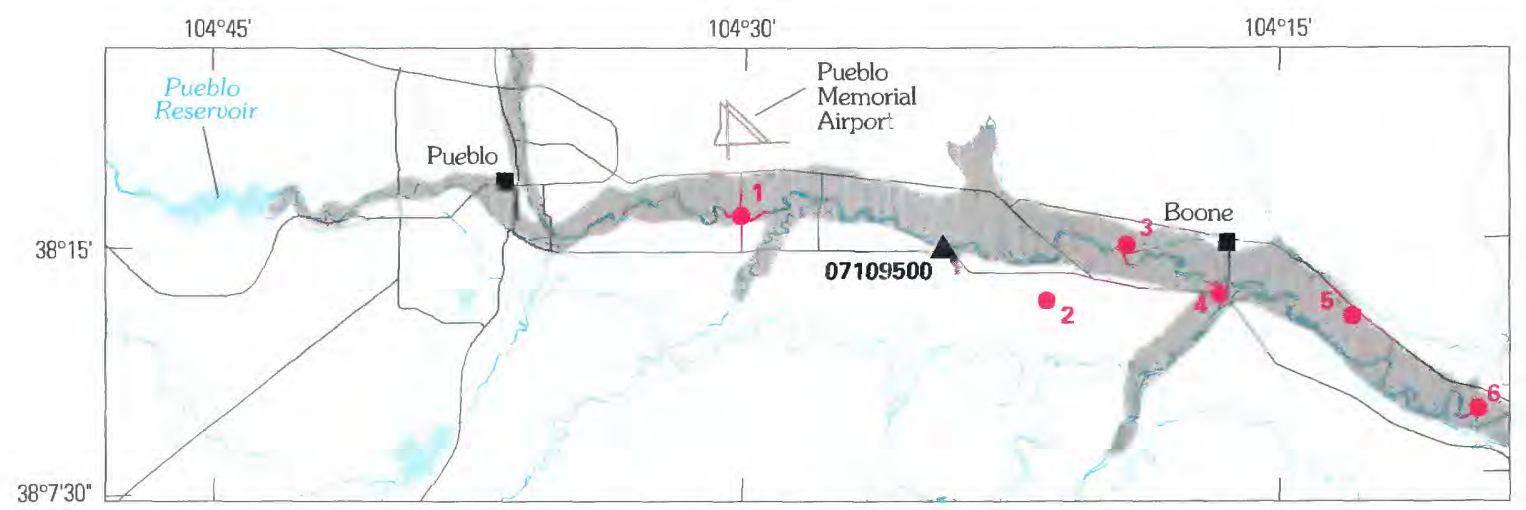

Figure 6. Locations of wells that have water-level data in Pueblo County.
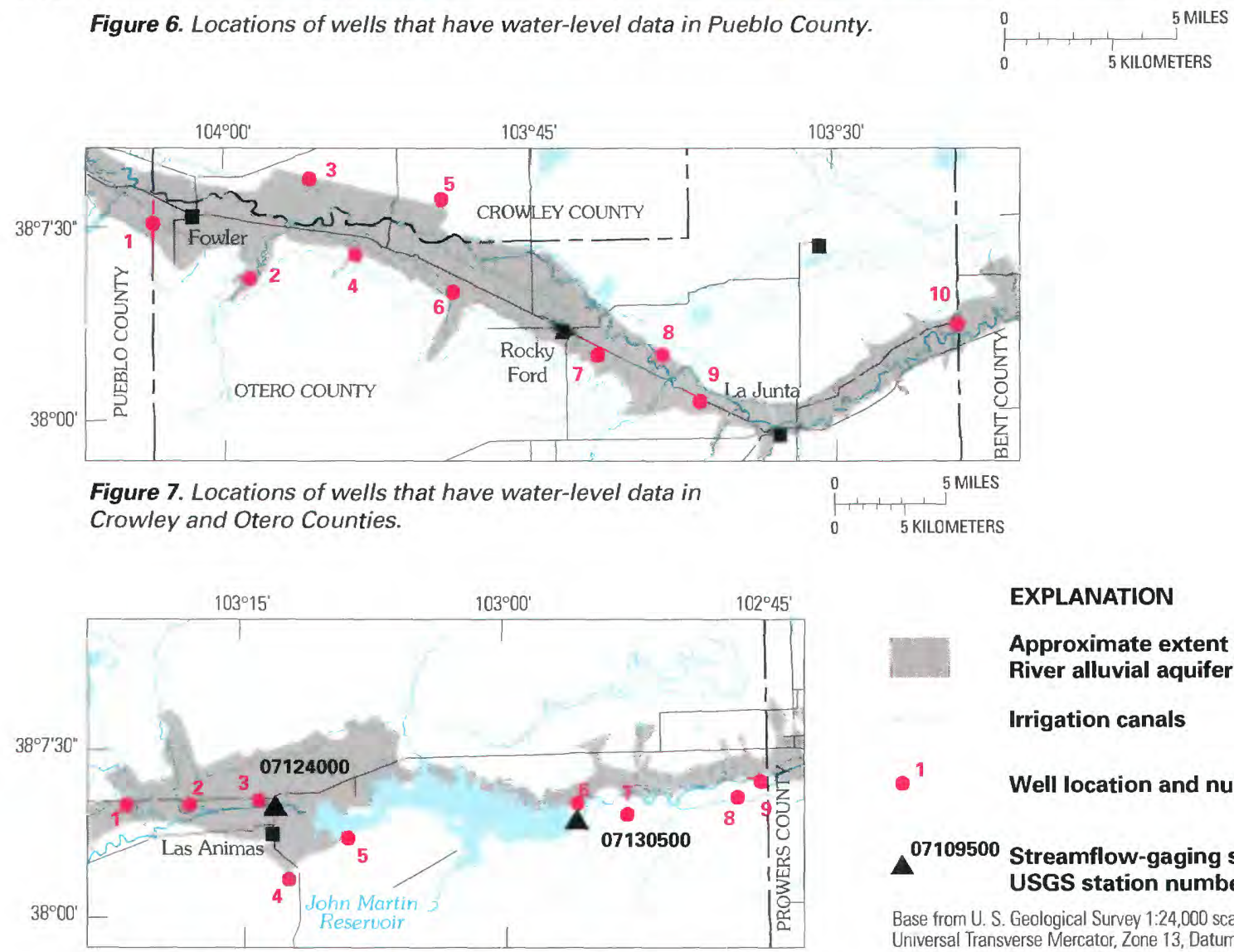

Figure 8. Locations of wells that have water-level 0 data in Bent County.

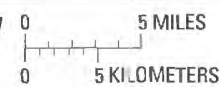

EXPLANATION

Approximate extent of Arkansas River alluvial aquifer

Irrigation canals

\section{Well location and number}

$A^{07109500}$ Streamflow-gaging station and USGS station number

Base from U. S. Geological Survey 1:24,000 scale Digital Line Graphs Universal Transverse Mercator, Zone 13, Datum NAD27.

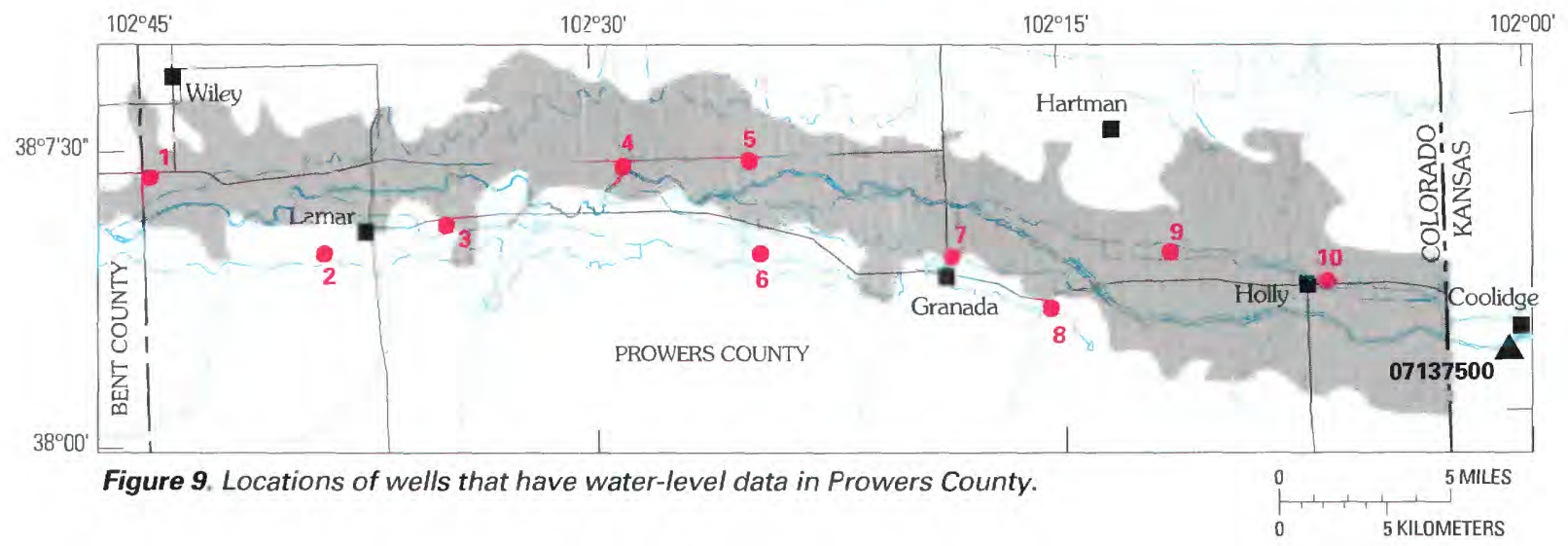




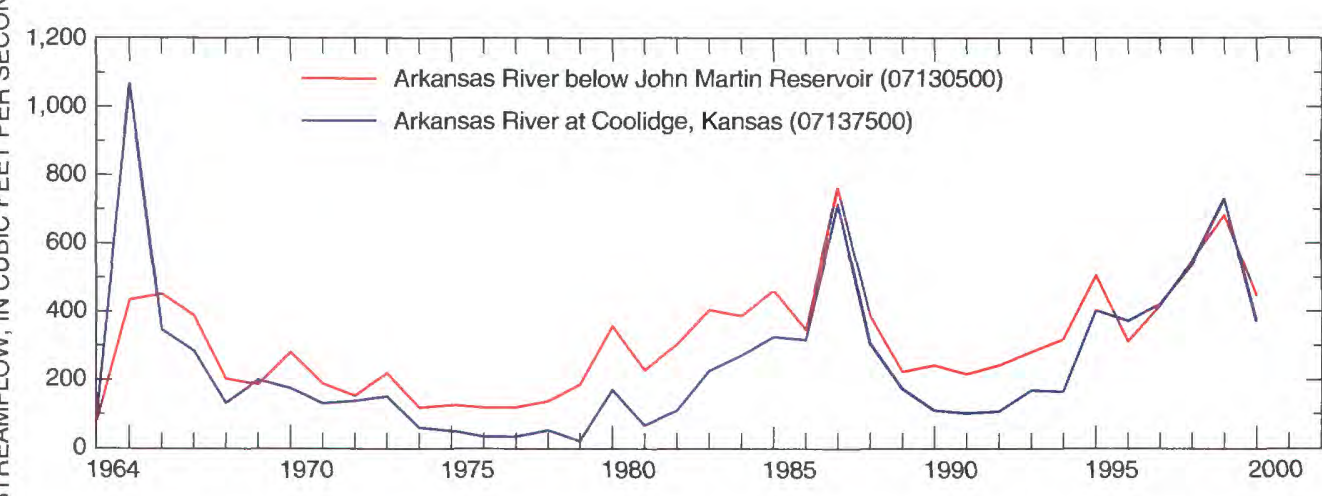

Figure 10. Mean annual streamflow downstream from John Martin Reservoir, 1964-2000.

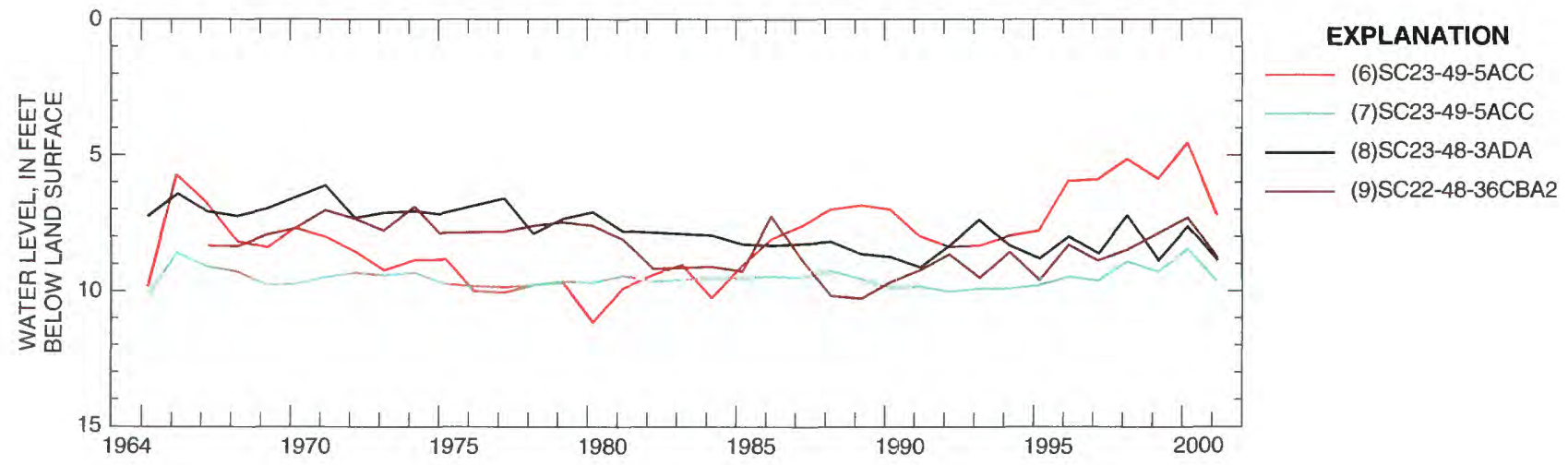

Figure 11. Water levels in selected wells in Bent County downstream from John Martin Reservoir, $1965-2001$.

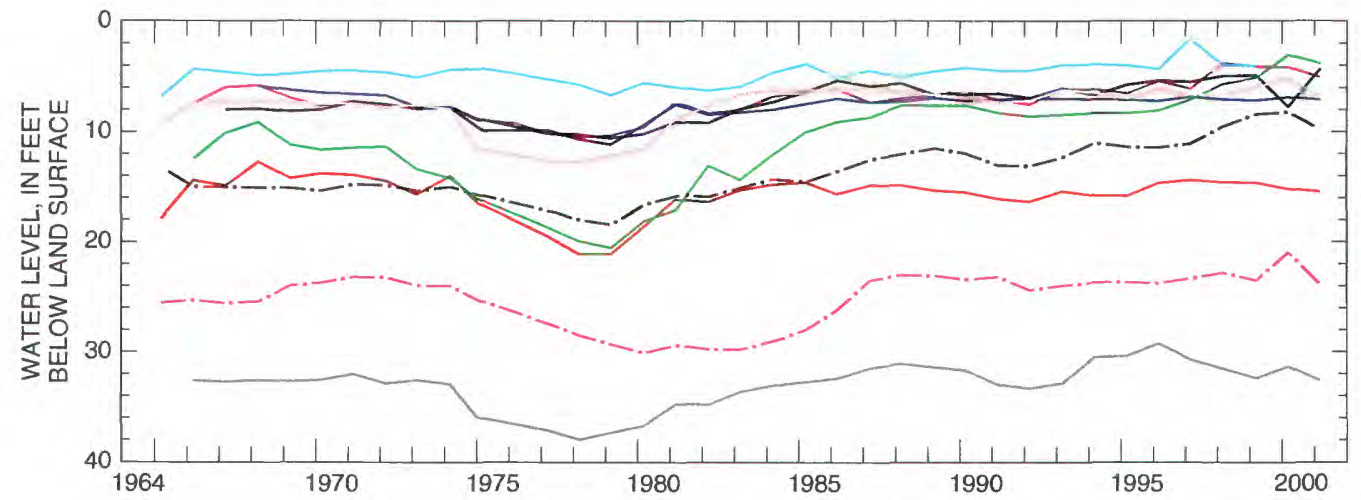

\section{EXPLANATION}

(1)SC22-47-19CCD2

(2)SC23-47-1BAC

(3)SC22-46-33DAA

(4) SC22-45-21CCC

(5)SC22-45-24DDC2

(6) $\mathrm{SC} 23-44-6 \mathrm{CBC}$

(7) SC23-44-1DCC

(8)SC23-43-16ACC2

(9)SC23-42-6CCC

(10)SC23-42-11DCC

Figure 12. Water levels in selected wells in Prowers County, 1965-2001. 
The Fryingpan-Arkansas Project, a multipurpose Bureau of Reclamation water-development project that diverts water from the Colorado River Basin to the Arkansas River, was built between 1963 and 1980 (Abbott, 1985). From 1972 through 1999, interbasin diversions averaged about 43,000 acre-feet per year (Southeastern Colorado Water Conservancy District, 2000) and resulted in increased streamflow in the Arkansas River. Since the late 1970 's, the WinterWater Storage Program (WWSP) has allowed irrigation canal companies to store winter-flow rights in Pueblo Reservoir and other reservoirs to be used during the growing season. The result of the WWSP has been a seasonal increase in streamflow and availability of surface water for irrigation in the Arkansas River valley downstream from Pueblo Reservoir.

The use of water from the Arkansas River is regulated by the operating principles of the Arkansas River Compact between Colorado and Kansas, which went into effect in 1948 (Radosevich and others, 1975). The 1980 operating plan for John Martin Reservoir has allowed year-round storage of water in the reservoir (Abbott, 1985) and has resulted in a seasonal increase in streamflow and availability of surface water for irrigation since the early 1980 's.

Colorado received greater-than-normal precipitation (rainfall and snowfall) during 1982-99 compared to any similar period during 1890-1999 (McKee and Doesken, 2000). Increased precipitation could account for increased streamflow in the Arkansas River since the late 1970 's. However, antecedent soil moisture conditions and timing of precipitation events (seasonality) can affect the amount of streamflow that results from increased precipitation.

The primary discharge of water from the Arkansas River alluvial aquifer is pumping from about 1.300 large-capacity wells (wells that discharge more than 50 gallons per minute) (Simpson, 1997) completed in the aquifer that are used to supplement the surface irrigation of about 300,000 acres of farmland (Cain, 1985). The operation of irrigation wells in the aquifer changed in the mid-1990's as a result of Arkansas River Compact issues and the adoption of rules by the Colorado State Engineer that may affect future water levels in the aquifer. The rules require discharge measurements of wells pumping ground water considered tributary to the Arkansas River and require replacement of depletions of streamflow in the Arkansas
River caused by pumping from the aquifer (Office of the State Engineer, 1994; 1996). Water is also discharged from the aquifer by seepage to the river and by evapotranspiration from shallow watertable areas.

\section{WATER-LEVEL CHANGES, BY COUNTY}

Water-level changes in aquifers are determined by making water-level measurements at selected time intervals. The water level is determined by measuring the distance between a stationary reference point (datum) on a well and the water level in a tightly cased well. Water-level data can be used to evaluate changes in depth to ground water, changes in ground-water storage, and the influence of surface water on ground water.

Streamflow data for the Arkansas River are presented in figures 2 and 10 .

Because of the direct relation between stream stage and streamflow, increasing streamflow is an indicator of increasing river levels, which in turn can influence ground-water levels in the Arkansas River alluvial aquifer. Mean annual calendar year streamflow for two streamflowgaging stations located upstream from John Martin Reservoir-Arkansas River near Avondale, Colorado (USGS station number 07109500) and Arkansas River at Las Animas, Colorado (USGS station number 07124000) - is shown in figure 2 , and station locations are shown in figures 6 and 8. Mean annual calendar year streamflow for two streamflow-gaging stations located downstream from John Martin Reservoir-Arkansas River below John Martin Reservoir (USGS station number 07130500) and Arkansas River at Coolidge, Kansas (USGS station number 07137500) - is shown in figure 10, and station locations are shown in figures 8 and 9.

Hydrographs of ground-water levels in selected wells for the counties included in this report are presented in figures 35, 11, and 12. Locations and map identification numbers for wells in each county are shown in figures 6-9. Map identification numbers are shown with the legal description (for example, SC20-6436DDD2) on the hydrographs. The legal description indicates the well location based on the township-range-section system of land subdivision. The letters after the number represent subdivisions of the section and are assigned in a counterclockwise direction beginning with ' $\mathrm{A}$ ' in the northeast quarter. The first letter indicates a 160-acre area, and each successive letter indicates an area one-fourth the size of the previous letter. The legal description, also known as the local well number, is stored in the USGS NWIS data base and can be used to access information for the wells.

An average water-level change for all wells in each county measured during 1965-2001 (1980-2001 in Pueblo County) was computed to evaluate long-term trends in ground-water levels. First, the individual water-level changes for each year during the period for each well in a county were determined by comparing the spring water-level measurement made in one year to the spring waterlevel measurement made the following year. Next, the net change for the water levels from a well measured during the period was computed by summing the individual water-level changes. The final step involved summing the net changes for all wells in a county and dividing the sum by the number of wells in the county to compute the average water-level change for all wells in the county. A positive average water-level change indicates that water levels predominantly increased during the period, whereas a negative average water-level change indicates that water levels predominantly decreased during the period. A positive or negative change could relate to indirect influence of streamflow caused by changes in availability of surface water. Spring waterlevel measurements represent the typical ground-water minima prior to snowmelt and diversion of streamflow for irrigation.

\section{Pueblo County}

Ground-water-level changes for six wells in eastern Pueblo County are shown in figure 3 , and well locations are shown in figure 6. Wells 2 and 4 have data beginning in 1965 and 1966, respectively, and the remaining wells have data beginning between 1969 and 1977. Well 2 is completed in the terrace alluvial aquifer of Quaternary age that is topographically higher and discharges to the Arkansas River alluvial aquifer. Water levels from well 2 can be used to evaluate long-term trends in ground-water levels adjacent to the Arkansas River alluvial aquifer in Pueblo County. Water levels in well 4 are influenced by streamflow, as water levels generally increased from the early 1980 's through the 1990's with increasing streamflow (fig. 2). The differences in depth to water in wells 1,3 , and 6 compared to wells 2,4 , and 5 likely result 
from differences in distance from the river or local irrigation practices. The average water-level change in the county from 1980 to 2001 was +1.23 feet based on data from the six wells that were measured during the period.

\section{Crowley and Otero Counties}

Ground-water-level changes for 10 wells in Crowley and Otero Counties are shown in figure 4. and well locations are shown in figure 7. All wells except for well 10 have data beginning in 1965 or early 1966. Water-level increases between 1965 and 1966 in wells $1,4,8$, and 9 could be attributed to the record floods during the summer of 1965 in the Arkansas River (Snipes and others, 1974). Water-level increases occurred in wells $1,4,8$, and 9 from the late 1970's to the mid-1980's. Water levels were generally stable during the 1990's except for well 5, which had minor increases and decreases through 2001. The average water-level change in the county from 1965 to 2001 was +3.27 feet based on data from nine wells that were measured during the period.

\section{Bent County}

Ground-water-level changes for nine wells in Bent County are shown in figures 5 and 11 , and well locations are shown in figure 8. Five wells are upstream from John Martin Reservoir (fig. 5) and four wells are downstream from the reservoir (fig. 11). All wells have data beginning in 1965-67. Similar to selected wells in Crowley and Otero Counties, water levels in wells 2,3,6,7, and 8 increased from 1965 to 1966 , possibly as a result of the record floods in the summer of 1965 in the Arkansas River Valley. Generally, water levels in wells 2,3 , and 4 located upstream from John Martin Reservoir increased during the late 1970 's and early 1980's and have continued either to rise slowly or remain fairly stable through 2001 . Water levels in wells located downstream from John Martin Reservoir have remained fairly stable or have slightly decreased until the 1990's. Water levels in well 6 show influence by streamflow (fig. 10). The average water-level changes for the wells upstream and downstream from John Martin Reservoir from 1965 to 2001 were +1.32 feet and +1.05 feet, respectively.

\section{Prowers County}

Ground water-level changes for 10 wells in Prowers County are shown in figure 12, and well locations are shown in figure 9.
All wells have data beginning in 1965-68. Water level increases in wells 1,2 , and 4 from 1965 to 1966 possibly resulted from the record floods in the summer of 1965 . Water levels in most wells decreased from the late 1960's to the mid-1970's. Since the late 1970's, the water levels have increased or remained fairly stable in different reaches and at different times during the study period. The long-term trends in water levels measured in wells in Prowers County generally show influence by streamflow (fig. 10). The average water-level change in the county from 1965 to 2001 was +3.40 feet.

\section{SUMMARY}

Water levels in the Arkansas River alluvial aquifer underlying the Arkansas River downstream from Pueblo Reservoir are influenced by streamflow. Groundwater levels measured in the cooperative program conducted by the SECWCD and the USGS and streamflow in the Arkansas River show the influence of surface water on water levels in several wells completed in the aquifer. The positive average waterlevel changes computed for all wells in Pueblo County for 1980-2001 and for all wells in Crowley, Otero, Bent, and Prowers Counties for 1965-2001 can be attributed to increased streamflow in the Arkansas River derived from interbasin diversions since completion of the Fryingpan-Arkansas Project and(or) to greater-than-normal precipitation. Water levels in wells also could be affected by other factors, including ground-water pumping, infiltration from irrigation canals, localized infiltration of rainfall or snowmelt, or evapotranspiration.

\section{REFERENCES}

Abbott, P.O., 1985, Description of water system operations in the Arkansas River Basin, Colorado: U.S. Geological Survey Water-Resources Investigations Report $85-4092,67$ p.

Bossong, C.R.. 2000, Analysis of hydrologic factors that affect ground water levels in the Arkansas River alluvial aquifer near La Junta, Colorado, 1959-99:

U.S. Geological Survey Water-Resources Investigations Report 00-4047, 26 p.

Cain, Doug, 1985, Quality of the Arkansas River and irrigation-return flows in the lower Arkansas River Valley, Colorado: U.S. Geological Survey Water-Resources Investigations Report 84-4273, 85 p.

Lohman, S.A., Burtis, V.M., and others, 1974, General availability of ground water and depth to water level in the Arkansas, White, and Red River basins: U.S. Geological Survey Hydrologic Investigations Atlas $\mathrm{HA}-3,1 \mathrm{pl}$.
McKee, T.B., and Doeskin, N.J., 2000, Drought in Colorado: Colorado Climate, winter 1999-2000, v. 1, no. 1, p. 13-20.

Office of the State Engineer, 1994, Rules governing the measurement of tributary ground water diversions located in the Arkansas River Basin: Denver, Colo., 4 p. (dated July 6, 1994) [Unpublished report available on file at the Office of the State Engineer, Division of Water Resources, Colorado Department of Natural Resources, 1313 Sherman Street, Denver, CO 80203]

Office of the State Engineer, 1996, Amendments to rules governing the measurement of tributary ground water diversions located in the Arkansas River Basin: Denver, Colo., 6 p. (dated February 28, 1996) [Unpublished report available on file at the Office of the State Engineer, Division of Water Resources, Colorado Department of Natural Resources, 1313 Sherman Street, Denver, CO 80203]

Radosevich, G.E., Hamburg, D.H., and Swick, L.L., 1975, Colorado water laws-A compilation of statutes, regulations, compacts, and selected cases: Fort Collins, Colorado State University, 3 volumes.

Simpson, H., 1997, State Engineer of Colorado, testimony Kansas vs. Colorado: Krause Shorthand Reporting Corporation. September 4, 1997.

Snipes, R. J., and others, 1974, Floods of June 1965 in Arkansas River Basin, Colorado, Kansas, and New Mexico: U.S. Geological Survey Water-Supply Paper 1850-D, 97 p.

Southeastern Colorado Water Conservancy District, 2000, 1999 Annual ReportSoutheastern Colorado Water Conservancy District: Pueblo, Colorado, 20 p.

Taylor, C.J., and Alley, W.M., 2001, Ground water-level monitoring and importance of long-term water-level data: U.S. Geological Survey Circular 1217, 68 p.

Voegeli, P.T., and Hershey, L. A., 1965 , Geology and ground-water resources of Prowers County, Colorado: U.S. Geological Survey Water-Supply Paper 1772, 101 p.

Weist, W.G., Jr., 1965, Geology and occurrence of ground water in Otero County and the southern part of Crowley County, Colorado: U.S. Geological Survey Water-Supply Paper 1799.90 p.

\section{-Ronnie D. Steger}

\section{For additional information contact:}

Subdistrict Chief

U.S. Geological Survey

201 W. 8th Street, Suite 200

Pueblo, Colorado 81003

(719)544-7155 